\title{
John Waldhausen, MD (1929-2012)
}

\author{
Lawrence H. Cohn, MD
}

We are saddened to report the passing of John A. Waldhausen, MD, of Hershey, Pa, the 6th Editor of The Journal of Thoracic and Cardiovascular Surgery (1995-2000) and the 72nd president of The American Association for Thoracic Surgery (1991-1992). As Editor, John did a tremendous job in expanding the scope and exposure of cardiothoracic topics. Under his leadership, Associate Editors in all 3 subspecialties of cardiothoracic surgery, as well as cardiothoracic physiology and support systems, were added. He also brought the JTCVS to the Internet through CTSNET, while the impact factor, under his direction, reached its highest level at that time, making it the leading journal in the field. Additionally, he oversaw the new production of our sister AATS publications, Seminars in Thoracic and Cardiovascular Surgery, Operative Techniques in Thoracic and Cardiovascular Surgery, and the Pediatric Cardiac Surgery Annual, all edited by Jimmy Cox of Washington University in St. Louis.

John was an academic cardiothoracic surgical superstar his entire career. He graduated from St. Louis University School of Medicine in 1954 and became an assistant resident in surgery at Johns Hopkins Hospital, where he met his lovely wife, Marian, who passed away this past February. They were married for 54 years. In 1957, he went to the National Heart Institute (NIH), where he became one of the early clinical investigators under Dr Glenn Morrow and where I was fortunate to have my first of many valuable interactions with him as an alumnus of NIH.

Following the conclusion of his time at the NIH, he went to the University of Pennsylvania and the University of Indiana to finish his surgical training. His first academic job was at Indiana University in 1962, where he stayed for 4 years and then returned to the Children's Hospital of the University of Pennsylvania (CHOP), where he held the rank of Associate Professor of Surgery.

In 1969, he became the first Professor and Chairman of the Department of Surgery at Penn State Hershey Medical Center, a position he held for 25 years until 1994. While there, he supported the development of the first artificial heart and served as a mentor to countless surgeons and staff.

Dr Waldhausen's memorable Presidential Address was titled, "The Association at 75: The challenge of the future. (Do we need a stress test?)" (J Thorac Cardiovasc Surg. 1992;104:1183-94). It detailed his forward thinking and passion for the field 25 years earlier, and its content is still very current concerning the issues cardiothoracic surgery faces today.

John was an outstanding academician, leader, innovator, Editor, and mentor to many and was one of the great intellects in the theory and practice of cardiothoracic surgery. He will be sorely missed. He is survived by his 3 sons, John, Robert, and Gordon, and 5 grandchildren. Memorial services were held at St. Patrick's Cathedral in Harrisburg, Pa, on June 23, 2012.

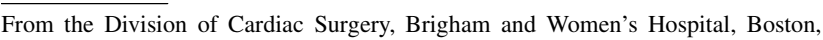
Mass.

Address for reprints: Lawrence H. Cohn, MD, Division of Cardiac Surgery, Brigham and Women's Hospital, 75 Francis St, Boston, MA 02115 (E-mail: lcohn@ partners.org).

J Thorac Cardiovasc Surg 2012;144:1

$0022-5223 / \$ 36.00$

Copyright (c) 2012 by The American Association for Thoracic Surgery

doi:10.1016/j.jtcvs.2012.05.074
} 